\title{
Immunogenicity and antigenicity of the recombinant EMA-1 protein of Theileria equi expressed in the yeast Pichia pastoris
}

Imunogenicidade e antigenicidade da proteína recombinante EMA-1 de Theileria equi expressa em Pichia pastoris

Leandro Q. Nizoli1*; Fabrí́cio R. Conceiçāo ${ }^{1}$; Sérgio S. Silva ${ }^{2}$; Luana A. Dummer ${ }^{1}$; Alceu G. Santos Jr. ${ }^{1}$; Fábio P. L. Leite ${ }^{1,3}$

${ }^{1}$ Centro de Biotecnologia, Universidade Federal de Pelotas - UFPel

${ }^{2}$ Departamento de Veterinária Preventiva, Faculdade de Veterinária, Universidade Federal de Pelotas - UFPel

${ }^{3}$ Departamento de Microbiologia e Parasitologia, Instituto de Biologia, Universidade Federal de Pelotas - UFPel

Received May 31, 2008

Accepted February 27, 2009

\begin{abstract}
The equine piroplasmosis caused by Theileria equi is one of the most important parasitic diseases of the equine, causing damage to animal health and economic losses. In T. equi, 2 merozoite surface proteins, equi merozoite antigen EMA-1 and EMA-2, have been identified as the most immunodominant antigens. This suggests that these antigens might be used as immunobiological tools. The EMA-1 of Theileria equi was cloned and expressed in the yeast Pichia pastoris. The transformed yeast was grown at high cell density, expressing up to $389 \mathrm{mg} . \mathrm{L}^{-1}$ of recombinant protein. The protein was concentrated and detected in Dot blot. The recombinant product was antigenically similar to the native protein as determined using monoclonal antibodies, and polyclonal antibodies obtained from equines naturally infected with T. equi. The immunogenicity of rEMA-1 protein was demonstrated by IFAT using sera from recombinantprotein-immunized mice using aluminum hydroxide as adjuvant. All animals vaccinated with rEMA-1 developed a high specific antibody response. This results suggest that rEMA-1expressed in P. pastoris might be a strong candidate to be used as an antigen for immune diagnostics as well as a vaccine antigen.
\end{abstract}

Keywords: Theileria equi, Pichia pastoris, EMA-1, recombinant vaccine.

\section{Resumo}

A piroplasmose equina causada por Theileria equi é uma das mais importantes doenças parasitárias de equídeos, causando danos a saúde animal e perdas econômicas. Em T. equi, 2 proteínas de superfície de merozoítos, equi merozoite antigen EMA-1 e EMA-2, têm sido identificadas como antígenos imunodominantes. Sugerindo que estes antígenos possam ser usados como produtos imunobiológicos. O gene EMA-1 de T. equi foi clonado e expressado na levedura Pichia pastoris. As leveduras transformadas foram cultivadas a altas densidades celulares expressando $389 \mathrm{mg} . \mathrm{L}^{-1}$ de proteína recombinante. A proteína foi concentrada e detectada em Dot blot. O produto recombinante foi antigenicamente similar à proteína nativa quando determinado usando anticorpo monoclonal e anticorpos policlonais obtidos de equinos naturalmente infectados com T. equi. A imunogenicidade da proteína rEMA-1 foi demonstrada por RIFI utilizando soro de camundongos imunizados com proteína recombinante usando hidróxido de alumínio como adjuvante. Todos os animais vacinados com rEMA-1 desenvolveram uma alta resposta específica de anticorpos. Esses resultados sugerem que rEMA-1 expressa em $P$. pastoris possa ser um candidato para ser usado como antígeno para diagnóstico imunológico bem como antígeno para vacinas.

Palavras-chave: Theileria equi, Pichia pastoris, EMA-1, vacina recombinante.

\section{Introduction}

Equine piroplasmosis is one of the most important parasitic diseases of the equines; it causes great damage to animal health. A haemoparasitosis caused by Theileria equi and Babesia caballi, equine

\footnotetext{
*Corresponding author: Leandro Q. Nizoli

Centro de Biotecnologia, Universidade Federal de Pelotas - UFPel,

Rua Gomes Carneiro 1, Centro, CP 354, CEP 96010-610 Pelotas - RS, Brazil; e-mail: lqn@pop.com.br; Supported by: CAPES
}

piroplasmosis is a tick-borne hemoprotozoan disease affecting horses worldwide (SCHEIN, 1988). Through infecting and destroying red blood cells, it can compromise the equine's functioning, leading to loss of vitality and decrease in the performance of infected animals. Equine piroplasmosis caused by T. equi is more pathogenic and widespread in horses than that caused by B. caballi (DE WAAL, 1992). It causes a persistent infection for which drug therapy 
or vaccination is not available (SCHEIN, 1988; FRIEDHOFF, 1990). Theileria equi infection is characterized by fever, anemia, icterus, and hepato and splenomegaly (OIE, 1989).

Merozoite surface proteins are important in the pathogenesis of hemoprotozoan diseases because of their role in parasite recognition of, attachment to, and penetration of host erythrocytes (JACK and WARD, 1981; KUMAR et al., 2004). In T. equi, 2 kinds of merozoite surface proteins, equi merozoite antigen EMA-1 and EMA-2, have been identified as the most immunodominant antigens (KAPPMEYER et al., 1993; KNOWLES et al., 1991; KNOWLES et al., 1992). EMA-1 is geographically conserved among all T. equi isolates (KNOWLES et al., 1991; CUNHA et al., 2002), and shares significantly high homologies in amino acid sequence with the counterpart proteins of many Theileria parasites (KAPPMEYER et al., 1993; KNOWLES et al., 1997). Additionally, EMA-1 has glycosyl-phosphatidylinositol (GPI) anchor-specific motifs in its sequence, suggesting that these proteins might be expressed on the outer surface of the merozoite with a GPI anchor (KNOWLES et al., 1997). Theileria equi merozoites express surface proteins of molecular mass $34 \mathrm{kDa}$, which are strongly recognized by antibodies produced in infected animals (KNOWLES et al., 1997; CUNHA et al., 2006). Further, EMA-1/2 are members of the major piroplasm surface protein (MPSP) family that is conserved among the genus Theileria, but the biological role of MPSP has not yet been clarified. Therefore, functional studies on EMA-1/2 family proteins may also provide insight into the biological significance of MPSP expression in the intra-erythrocytic development of Theileria parasites (KUMAR et al., 2004).

The methylotrophic yeast Pichia pastoris is one of the dominant expression systems in molecular biology due to its stable and high-level expression of heterologous proteins (CREGG et al., 1993, DALY and HEARN, 2005). Over 400 proteins from prokaryotes, eukaryotes, and viruses have now been successfully expressed in this yeast (CEREGHINO et al., 2002). The P. pastoris expression system offers many advantages, including its ease of usage relative to other eukaryotic expression systems, and the possibility of high-level expression of foreign proteins. The yeast is also able to introduce eukaryotic post-translational modifications such as glycosylation and proteolytic processing (CEREGHINO and CREGG, 2000).

The present study aims to express the truncated EMA-1 gene by $P$. pastoris system and subsequently determine the immunologic and antigenic properties of recombinant EMA-1 protein.

\section{Materials and Methods}

\section{Transformation of P. pastoris and expression in shaken flasks}

The transformation of $P$. pastoris and cultivation in shaken flasks were performed according to the EasySelect ${ }^{\mathrm{TM}}$ Pichia Expression Kit (Invitrogen, Catalog No. K1740-01). A DNA encoding the EMA-1 from T. equi was obtained as previously described by Nicolaiewsky et al. (2001). The EMA-1 gene
(GenBank accession number AF261824) was amplified by PCR with the following primers: forward (5'-CGGAATTC ACAAAATGGAGGAGGAGAAACCCAAG-3') and reverse (5'-GGTACCAATAGAGTAGAAAATGCAATG-3'), containing an EcoRI (forward) site and an XbaI site (reverse), respectively. After purification and digestion, the amplified DNA fragment was cloned into the vector. The Escherichia coli TOP10F were used as a host for plasmid propagation. The $P$. pastoris wild type strain $\mathrm{X}-33$ and $\mathrm{pPICZ} \alpha \mathrm{B}$ vector were used as a host for expression of EMA-1 in P. pastoris. The P. pastoris transformants were selected in YPD containing $100 \mathrm{mg} \cdot \mathrm{mL}^{-1}$ zeocin.

\section{Precipitation of protein}

Proteins in the media were precipitated by addition of solid ammonium sulfate to $80 \%$ and incubation at $4{ }^{\circ} \mathrm{C}$ for 16 hours. Precipitated protein was pelleted by centrifugation at $12.000 \mathrm{~g}$ for 15 minutes and the pellet was resuspended in buffer PBS. The solution was desalted by overnight dialysis against buffer PBS at $4{ }^{\circ} \mathrm{C}$. Protein quantitation was determined using the $\mathrm{BCA}^{\mathrm{Tm}}$ Protein Assay Kit (Pierce Chemical Company) with bovine serum albumin as a standard.

\section{Dot blot}

Dot blot assays were performed using $20 \mu \mathrm{L}$ of samples $(-8 \mu \mathrm{g}$ of recombinant protein). As a negative control, $20 \mu \mathrm{L}$ of a membrane preparation from $P$. pastoris clone was transformed with the empty expression vector. The proteins were spotted onto a nitrocellulose membrane (Hybond C, Amersham Biosciences). The nitrocellulose membranes were blocked for 1 hour at room temperature in PBST buffer containing 5\% of non-fat milk. 1 membrane was incubated with monoclonal antibody anti-His peroxidase conjugate and the other membrane with monoclonal antibody anti-EMA-1. 2 membranes were incubated with serum of equines negative and positive for infection of T. equi, respectively. Membranes were incubated with secondary antibodies for 1 hour with goat anti-horse or anti-mouse IgG peroxidase conjugate. The reaction was developed with diaminobenzidine (Sigma).

\section{Immunization of mice}

The recombinant purified protein was prepared for immunization of mice (Mus muscullus). Female BALB/c mice (6 weeks old) were randomly divided into three groups (4 mice per group) and subcutaneously immunized twice at a 10-day interval. One group (GI) was injected with EMA-1 protein $(50 \mu \mathrm{g})$ without adjuvant. The second group (GII) was injected with $50 \mu \mathrm{g}$ of EMA-1 protein formulated with the adjuvant aluminum hydroxide. The final group (GIII) was used as a negative control and injected with $100 \mu \mathrm{l}$ of sterile PBS. Serum samples were collected from the retro-orbital plexus immediately before immunization and about 10 days after each of the immunizations and used in serological tests. The experiment was approved by the UFPel Committee of Ethics in Animal Experimentation. 


\section{Immunofluorescence assay}

Antibody titers of the serum samples against the recombinant protein were measured with IFAT. The slides were prepared with infected-equine erythrocytes visible as compact inclusion by IFAT staining. IFAT was performed according to Cunha et al. (1993). Then polled serum from the different groups were added, and FITC-conjugated goat anti-mouse IgG (Invitrogen) was applied per well and diluted at 1:400 in PBS buffer. The visualization slides were in epifluorescent microscopy (Olympus, BX-FLA).

\section{Results and Discussion}

\section{Expression and purification of $r E M A-1$ in P. pastoris}

The Pichia pastoris gene expression system is an attractive method with which to produce a variety of intercellular and extracellular proteins (CREGG et al., 1993). Since we previously isolated a DNA encoding this protein, we decided to clone the DNA sequence encoding EMA-1 without its native signal peptide in $P$. pastoris pPICZ $\alpha \mathrm{B}$ plasmid, in frame with the yeast a-factor signal sequence, for secretion of protein containing a $6 \mathrm{His}-\mathrm{Tag}$ at its C-terminus. The pPICZ $\alpha \mathrm{B}-\mathrm{EMA}-1$ plasmid was then transformed and targeted to the $P$. pastoris genome by means of homologous recombination. The presence of the EMA-1 coding sequence in the genomic DNA isolated from Pichia transformants was confirmed by PCR. In the P. pastoris expression system, recombinant protein expression is strictly controlled by the AOX1 promoter. Expression was induced by addition of methanol to a final methanol concentration of $0.5 \%$. A protein that was not present before methanol induction was detected by SDS-PAGE (data not shown).

One of the main advantages in producing heterologous proteins as secreted products in $P$. pastoris is the easy isolation of the recombinant product from the medium in which it is produced. Indeed, the initial purity of recombinant molecule in culture medium is high because the level of endogenous secreted proteins is very low. Thus, after removal of the yeast cells by centrifugation, proteins in the culture supernatant were precipitated with $80 \%$ ammonium sulfate fractionation. The final yield of the purified protein was $389 \mathrm{mg}$ of rEMA-1 per liter of cell culture supernatant.

\section{Detection of reactivity to recombinant EMA-1}

Dot blot is a technique for detecting and identifying proteins, similar to the Western blot technique but differing in that protein samples are not separated electrophoretically but are spotted through circular templates directly onto the membrane. Antigens may be applied directly to nitrocellulose membrane as a discrete spot (dot) to give a simple and reliable assay.

In order to evaluate the reactivity of recombinant EMA-1 with sera from T. equi positive and negative equines, we tested by Dot blot. Positive samples were considered all of those that developed a reaction color. Negative controls samples did not develop any color.

In Dot blots, we are able to observe that the rEMA-1 protein reacted with the serum from horses naturally infected by T. equi, but did not react with the serum of the negative horse.

Figure 1 shows the reactivity of the rEMA-1 protein using anti-histidine monoclonal antibody, monoclonal antibody anti-EMA-1, and serum of equine positive carrier of T. equi, and does not show reactivity with serum of the negative animal. No reactivity was observed with control negative protein.

\section{Immunogenicity of the rEMA-1 protein in mice}

Mice immunized with the recombinant protein showed high antibody response and were able to react with native EMA-1 of $T$. equi as observed by IFAT. Sera from the negative control group did not react with native EMA-1, showing the specificity of the response (Figure 2). These results indicate that immune response was generated in all the vaccinated groups, showing that recombinant protein has capability to generate antibodies that react with the native protein. We also observed that the antibody titers have significant difference between the groups with and without adjuvant. It is worth noting that rEMA-1 expressed in P. pastoris maintains the same three-dimensional structure as the native protein since it was recognized by antibodies generated by naturally infected horses.

The Pichia pastoris expression system has been used for the production of a wide variety of proteins (CEREGHINO and CREGG, 2000). However, to the best of our knowledge this is the first report on the cloning and expression of EMA-1 protein in $P$. pastoris.

In conclusion, the production and purification of rEMA-1 in the methylotrophic yeast $P$. pastoris was effective, permitting a high-yield production of this protein. Thus, rEMA-1 expressed in P. pastoris might be a strong candidate to be used as an antigen for immune diagnostics as well as a vaccine antigen.
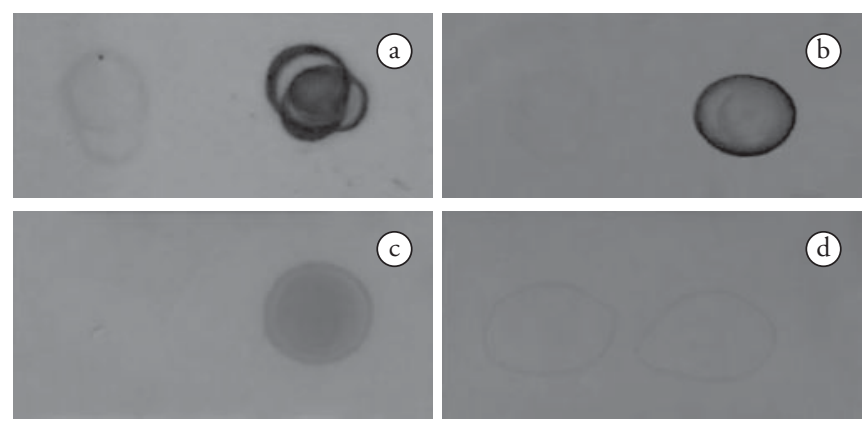

Figure 1. rEMA-1 Dot blot. Reactivity against different antibodies: a) anti-histidine monoclonal antibody; b) anti-EMA-1 monoclonal antibody; c) sera from positive equine; d) sera from negative equine. At the left of each membrane was spotted a negative control, and at the right the rEMA-1 protein. 

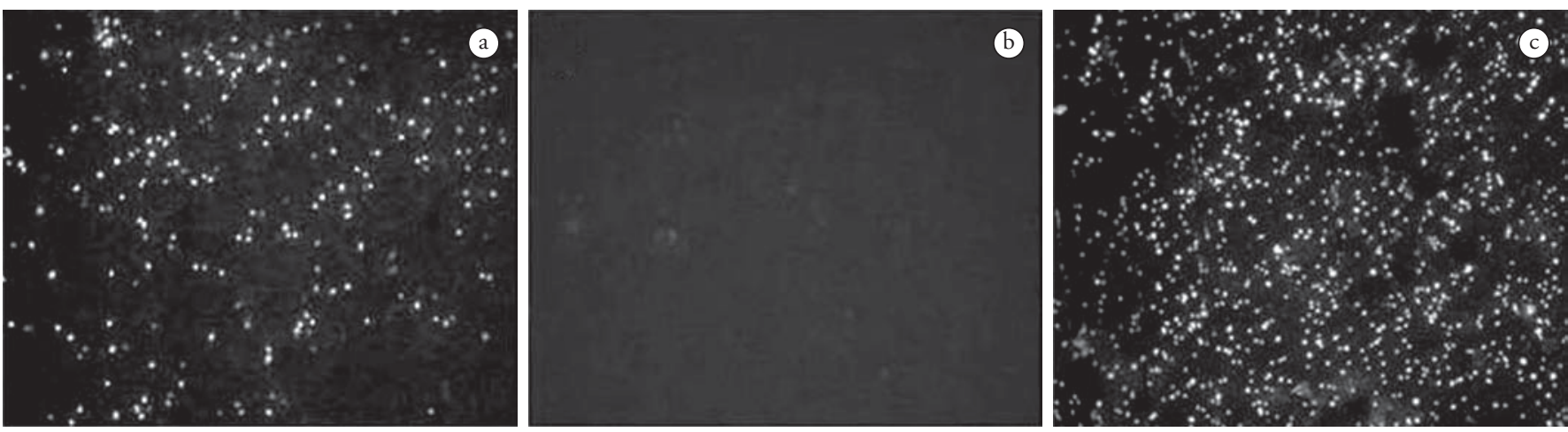

Figure 2. IFAT of sera from immunized mice with rEMA-1: a) pool of sera from mice immunized twice in the presence of adjuvant; b) mice immunized with sterile PBS; c) IFAT positive control (equine sera with FITC anti-equine).

\section{References}

CEREGHINO, G. P. L. et al. Production of recombinant proteins in fermenter cultures of the yeast Pichia pastoris. Current Opinion in Biotechnology, v. 13, n. 4, p. 329-332, 2002.

CEREGHINO, J. L.; CREGG, J. M. Heterologous protein expression in the methylotrophic yeast Pichia pastoris. FEMS Microbiology Reviews, v. 24, n. 1, p. 45-66, 2000.

CREGG, J. M.; VEDVICK, T. S.; RASCHKE, V. Recent advances in the expression of foreign genes in Pichia pastoris. Biotechnology, v. 11, n. 8, p. 905-910, 1993.

CUNHA, C. W. Babesiose Equina: padronização da reação de imunofluorescência para sorodiagnóstico e levantamento epidemiológico em eqüinos Puro Sangue Inglês. 1993. 57 p. Dissertaçáo (Mestrado em Veterinária) - Universidade Federal de Pelotas, Pelotas.

CUNHA, C. W. et al. Conformational dependence and conservation of an immunodominant epitope within the Babesia equi erythrocyte-stage surface protein equi merozoite antigen 1. Clinical and Diagnostic Laboratory Immunology, v. 9, n. 6, p. 1301-1306, 2002.

CUNHA, C. W. et al. Development of specific immunoglobulin Ga (IgGa) and IgGb antibodies correlates with control of parasitemia in Babesia equi infection. Clinical and Vaccine Immunology, v. 13, n. 2, p. 297-300, 2006.

DALY, R.; HEARN, M. T. W. Expression of heterologous proteins in Pichia pastoris: a useful experimental tool in protein engineering and production. Journal of Molecular Recognition, v. 18, n. 2, p. 119-138, 2005.

De WAAL, D. T. Equine piroplasmosis: a review. British Veterinary Journal, v. 148, n. 1, p. 6-14, 1992.

FRIEDHOFF, K. T. Interaction between parasite and tick vector. International Journal for Parasitology, v. 20, n. 4, p. 525-535, 1990.
JACK, R. M.; WARD, P. A. Mechanisms of entry of Plasmodium and Babesia into red cells. In: RISTIC, M.; KREIER, J. P. (Eds.). Babesiosis. New York: Academic Press, 1981. p. 445-458.

KAPPMEYER, L. S.; PERRYMAN, L. E.; KNOWLES Jr., D. P. A Babesia equi gene encodes a surface protein with homology to Theileria species. Molecular and Biochemical Parasitology, v. 62, n. 1, p. 121-124, 1993.

KNOWLES Jr., D. P. et al. A monoclonal antibody defines a geographically conserved surface protein epitope of Babesia equi merozoites. Infection and Immunity, v. 59, n. 7, p. 2412-2417, 1991.

KNOWLES Jr., D. P. et al. Antibody to a recombinant merozoite protein epitope identifies horses infected with Babesia equi. Journal of Clinical Microbiology, v. 30, n. 12, p. 3122-3126, 1992.

KNOWLES Jr., D. P.; KAPPMEYER, L. S.; PERRYMAN, L. E. Genetic and biochemical analysis of erythrocyte-stage surface antigens belonging to a family of highly conserved proteins of Babesia equi and Theileria species. Molecular and Biochemical Parasitology, v. 90, n. 1, p. 69-79, 1997.

KUMAR, S. et al. Expression of Babesia equi EMA-1 and EMA-2 during merozoite developmental stages in erythrocyte and their interaction with erythrocytic membrane skeleton. Molecular and Biochemical Parasitology, v. 133, n. 2, p. 221-227, 2004.

NICOLAIEWSKY, T. B. et al. Detection of Babesia equi (Laveran, 1901) by nested polymerase chain reaction. Veterinary Parasitology, v. 101, n. 1, p. 9-21, 2001.

OFFICE INTERNATIONAL DES ÉPIZOOTIES - OIE. Manual of recommended diagnostic techniques and requirements for biological products for lists A and B diseases - Equine Piroplasmosis. Disponível em: http://www.oie.int/eng/normes/mmanual/A_00084.htm. Acesso em: 17 de Dezembro de 2007.

SCHEIN, E. Equine babesiosis. In: RISTIC, M. (Ed.). Babesiosis of domestic animals and man. Boca Raton: CRC Press, 1988. p. 197-208. 